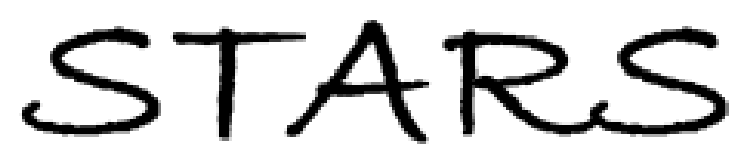

University of Central Florida

STARS

Faculty Bibliography 2000s

Faculty Bibliography

$1-1-2000$

\title{
Adolph Fick: Mathematician, physicist, physiologist
}

Louis J. Acierno

University of Central Florida

Find similar works at: https://stars.library.ucf.edu/facultybib2000 University of Central Florida Libraries http://library.ucf.edu

This Biographical-Item is brought to you for free and open access by the Faculty Bibliography at STARS. It has been accepted for inclusion in Faculty Bibliography 2000s by an authorized administrator of STARS. For more information, please contact STARS@ucf.edu.

\section{Recommended Citation}

Acierno, Louis J., "Adolph Fick: Mathematician, physicist, physiologist" (2000). Faculty Bibliography 2000s. 2413.

https://stars.library.ucf.edu/facultybib2000/2413

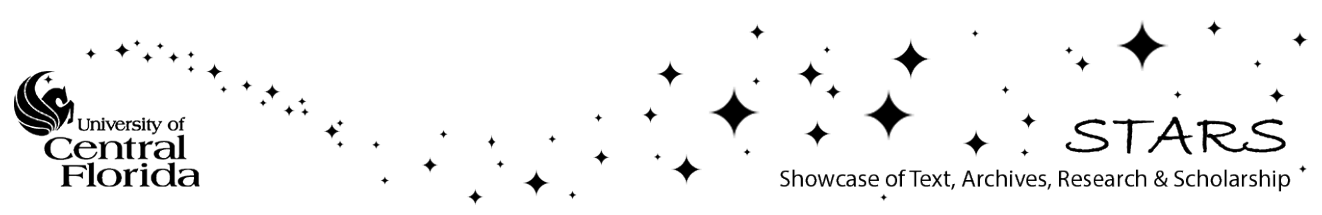


$\mathrm{ABOVE}$

AND

BEYOND

Evolut $^{\mathrm{TM}}$

TAVR Platform

$\nabla$ LEARN MORE

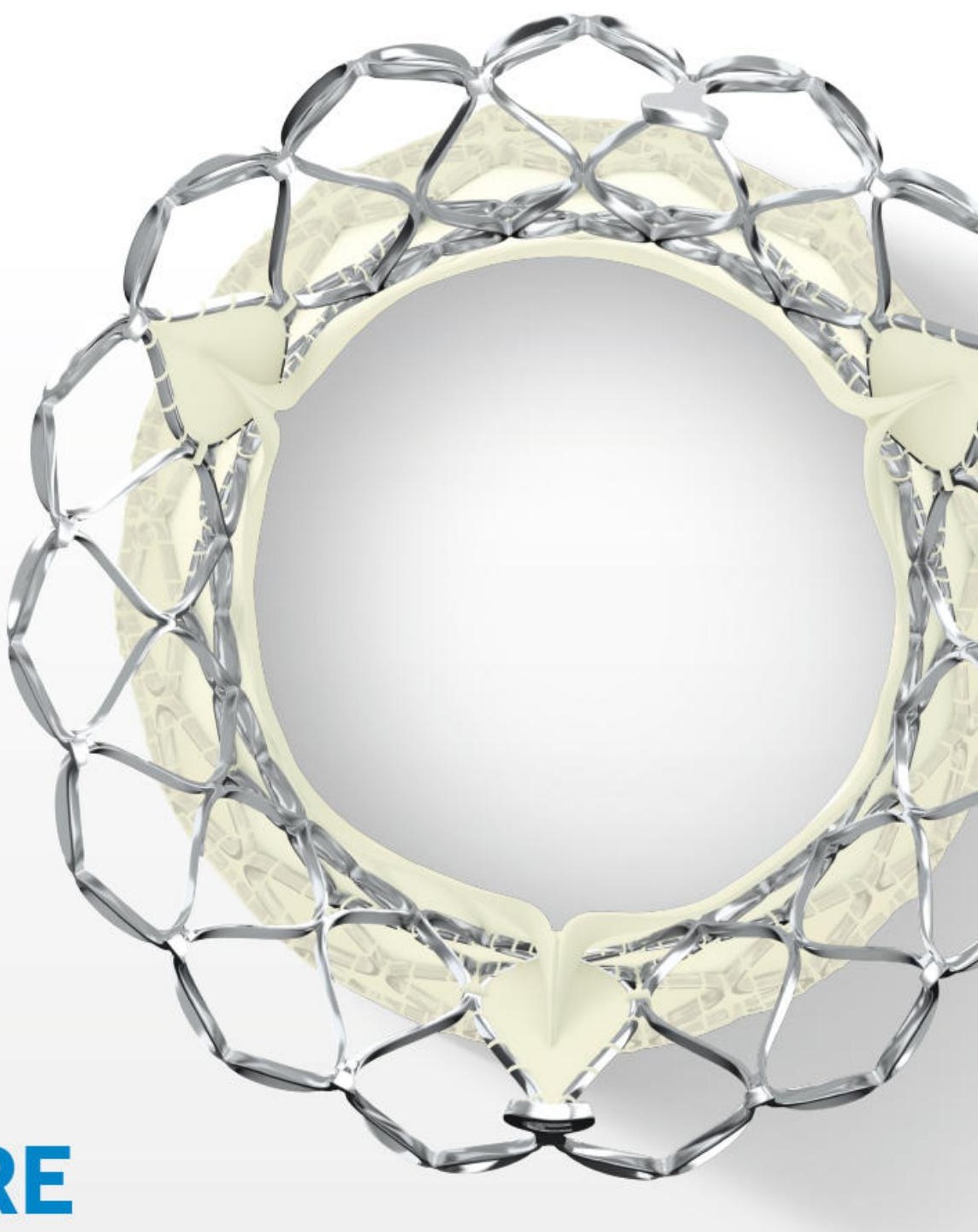




\title{
Profiles in Cardiology
}

\section{Adolph Fick: Mathematician, Physicist, Physiologist}

\author{
LOUIS J. ACIERNO, M.D., FACC \\ Cardiopulmonary Sciences, Department of Health Professions and Physical Therapy, University of Central Florida, Orlando, \\ Florida, USA
}

The scion of an architect, and the last to join a family of scholars that eventually counted among eight siblings a professor of anatomy and one of law, Adolph Fick (Fig. 1) made his entry into this world in 1829 in Cassel, Germany. Early in life, Adolph showed a remarkable talent for mathematics and physics. He enrolled at the University of Marburg with the express purpose of acquiring the appropriate academic credentials in these two related disciplines. However, under the prodding of his brother Heinrich, who was professor of law, young Adolph was persuaded to matriculate in medicine, a field that Heinrich felt would certainly benefit from Adolph's expertise in mathematics and physics. I

Soon after taking his medical degree, Fick turned his attention to physiology, accepting a prosectorship with Carl Ludwig in Zurich. The year was 1852 and Fick was a mere 23 years of age. He was to remain with Ludwig for 16 years, leaving Zurich to accept the chair of physiology in Würzburg. Throughout his stay at Zurich, Fick made many contributions as a scientist well versed in mathematics, physics, and physiology, as brother Heinrich had already perceived. He was a quiet, scholarly man whose pastimes included pursuit of his marked interest in philosophy and literature.

Fick's first contribution as a physicist was made in 1855 when he was just 26 years old. It consisted of a concept that he developed mathematically from Fourier's theory of heat equilibrium. The resulting statement put forth the physically

Address for reprints:

Louis J. Acierno, M.D., FACC

Professor

Cardiopulmonary Sciences

Dept. of Health Professions and Physical Therapy

University of Central Florida

P.O. Box 162400

Orlando, FL 32816-2205, USA

Received: July 2, 1999

Accepted: July 2, 1999 sound and logical view that diffusion is proportional to concentration gradient. Experimental proof of the view was provided 25 years later. ${ }^{2}$

A year after this distinctive achievement, Fick published a well-rounded monograph entitled Medical Physics. ${ }^{3}$ Here, for the first time, he introduced his thoughts on certain physiologic problems such as the mixing of air in the lungs, measurement of carbon dioxide output in humans, the heat economy of the body, and the work of the heart. The monograph was a gold mine of information. Aside from a detailed discussion of the mechanics of muscular contraction and the molecular physics of gases and water, optics, color vision, animal heat, and conservation of energy, it dealt with hydrodynamics of the circulation fortified with sound recordings of circulatory events. It was the first book of its kind, and medicine had to wait almost a century before it yielded its landmark status to Otto Glasser's monumental Medical Physics. ${ }^{4}$

Throughout his tenure of more than three decades at Würzburg, and in his quiet unassuming manner, Fick contributed a steady and focused stream of information that was always on the cutting edge of knowledge in the three disciplines that he mastered. Although his major field of inquiry was devoted to the physiology of muscular contraction, he utilized the experimental knowledge gained from this activity to elucidate in quantitative terms the calculation of cardiac output. In fact, Fick is immortalized in cardiology because of a brief and obscure publication in 1870 wherein he described how mass balance might be used to measure cardiac output. It was a mathematical concept so pure in its logic that it contained sui generis its own intrinsic proof for its validity. The concept was an outgrowth of his mathematical approach to physiologic events. ${ }^{1}$

The concept now known as the Fick principle was published in the brief proceedings of the Wuirzburg Physikalische Medizinische Gesellschaft for July $9,1870 .^{5}$

The following is an account of his presentation before the society:

It is astonishing that no one has arrived at the following obvious method by which [the amount of blood ejected by the ventricle of the heart with each systole] may be determined directly, at least in animals. One measures 


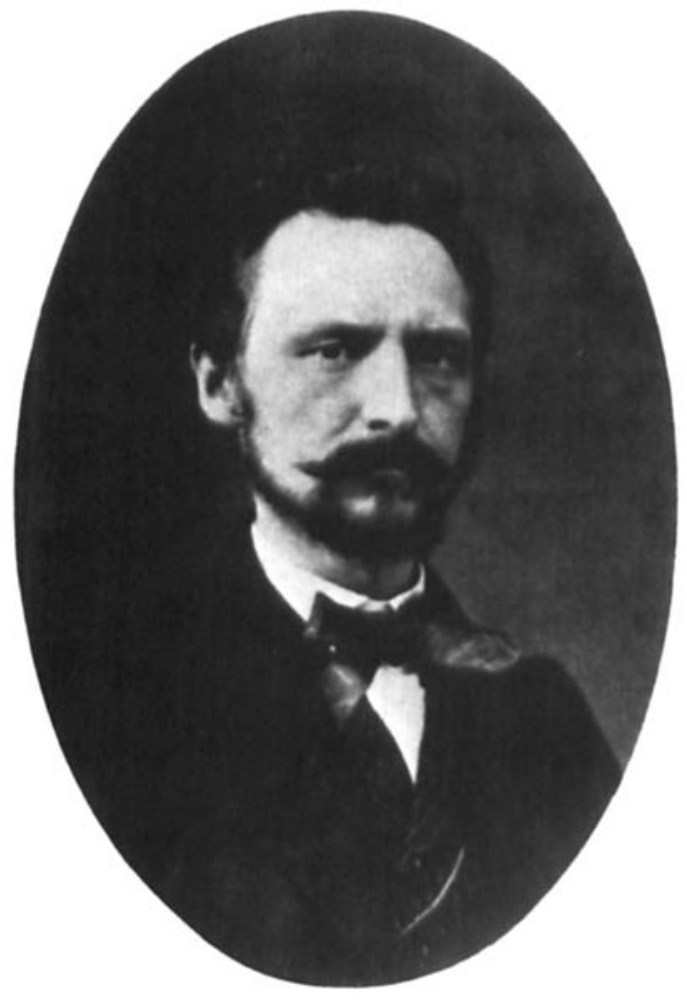

FIG. 1 Adolph Fick, 1829-1901. Source: Fishman AP, Richards DW: Circulation of the Blood: Men and Ideas, p. 94. New York: Oxford University Press, 1964. Reproduced with permission.

how much oxygen an animal absorbs from the air in a given time, and how much carbon dioxide it gives off. During the experiment one obtains a sample of arterial and venous blood; in both the oxygen and carbon dioxide content are measured. The difference in oxygen content tells how much oxygen each cubic centimeter of blood takes up in its passage through the lungs. As one knows the total quantity of oxygen absorbed in a given time one can calculate how many cubic centimeters of blood passed through the lungs in this time. Or if one divides by the number of heart beats during this time one can calculate how many cubic centimeters of blood are ejected with each beat of the heart. The corresponding calculation with the quantities of carbon dioxide gives a determination of the same value, which controls the first. ${ }^{5}$

It is of interest that the preceding item in the proceedings announces the election of Wilhelm Roentgen to the society.

The physical law that underlies Fick's principle is that matter can neither be created nor destroyed. Thus, the volume of oxygen taken up by the lungs must be equal to the amount of oxygen used by the tissues. Fick's principle is expressed by the following equation:

$$
\text { Cardiac output }=\frac{\text { oxygen consumption }}{\text { arteriovenous oxygen difference }}
$$

As usual, Fick did not bother either to advance or investigate the experimental proof for his principle. It was not until Grehant and Quinquad in 1886 that the validity of the Fick principle was demonstrated. ${ }^{6}$ Further experimental proof was supplied by Zuntz and Hagemann, just three years before Fick's death. ${ }^{7}$ Verification of the Fick principle in humans was initially accomplished in 1930. It was made possible through the daring exploits of Baumann and Grollman ${ }^{8}$ at a time when cardiac catheterization had yet to be established as a clinical tool. They obtained samples of mixed venous blood by inserting a spinal tap needle just to the right of the sternum that entered the right ventricular chamber by puncturing its wall. ${ }^{8}$

Fick was also an innovator and inventor of sorts. Among the many instruments that he devised, some of those that had an impact on cardiovascular physiology were the plethysmograph, the pneumograph, and his version of the aneroid manometer. These were a reflection of his desire to attain precision in his physiologic experiments.

Fick remained at Würzburg for 31 years during which time he created an institute of physiology that became known as one of the foremost centers of its kind throughout the world. Over the years, in addition to his teaching and research activities, he climbed the academic ladder, finally becoming rector of the university. In turn, his own family continued the scholarly tradition of his father's family. His sons apparently inclined toward their uncle's choice of professions, one becoming an anatomist and the other a jurist. ${ }^{1}$

Fick relinquished his teaching duties on his 70 th birthday by declaring that it was time for younger men to carry on this function. Despite his apparent good health he died of apoplexy only a year later. His sons memorialized him through the creation of the Adolph Fick Fund which awards a prize every five years for an outstanding contribution to physiology.

Although errors can occur in applying the Fick principle, as Guyton pointed out in 1930, these errors are small and in no way diminish its value. ${ }^{9}$ It is fitting at this point to let it be known that Adolph Fick shall always be remembered as the mathematician and physicist who expanded the horizons of physiology and left a lasting impact on the determination of cardiac output.

\section{References}

1. Shapiro E: Adolph Fick-forgotten genius of cardiology. Am J Cardiol 1972;30:662-665

2. Fick A: Über Diffusion. Ann Phys 1855;94:59

3. Fick A: Die Medizinische Physik. Vieweg: Braunschweig, 1856

4. Acierno LJ: The History of Cardiology. London, New York: The Parthenon Publishing Group, 1994

5. Fick A: Über die Messung des Blutquantums in den Herzventrikeln. Würzburg: SB-Phys-Med Ges, July 9, 1870

6. Grehant N, Quinquad CE: Recherches expérimentales sur la mesure du volume de sang qui traverse les poumons en un temps donné. CR Soc Biol Paris 1886;36:285

7. Zuntz N, Hagemann O: Untersuchungen über den Stoffwechsel des Pferdes bei Ruhe und Arbeit. Landw Jh 1898;27 (Ergänz. Bd. 3)

8. Grollman A: The Cardiac Output in Man in Health and Disease, p. 11. Springfield, Illinois: Charles C. Thomas, 1932

9. Guyton AC: Cardiac Output and Its Regulation, p. 30. Philadelphia: W. B. Saunders, 1930 